\title{
Silat as the Source and Identity of the Minangkabau Ethnic Dance
}

\author{
Afifah Asriati ${ }^{\bowtie}$, Ahmad Kosasih, Desfiarni \\ Department of Drama, Dance and Music, Faculty of Languages and Art, \\ Universitas Negeri Padang, Indonesia
}

Received: September 24, 2018. Revised: January 4, 2019. Accepted: May 28, 2019

\begin{abstract}
This article is intended to get the concept of Minangkabau dance movement in the context of ethnic philosophical values. Today, ninik-mamak, cadiak pandai, and alim ulama in West Sumatra develop ideas about Minangkabau philosophy in all aspects of life. How this idea is reflected in dance movements? To answer this question, a qualitative method is used by taking six samples of popular Minangkabau traditional dance. The data were collected using Focus Group Discussion, observation, and interviews to confirm previous findings. Through the triangulation technique, it is expected to obtain credible data and be analyzed using the models of Miles and Haberman. The results of this study indicate that the basic movements of Minangkabau dance are silat movements. The martial arts movement is the basis of movement used by many traditional dances in Minangkabau. Every district has its unique cultural values and identities and these values are manifested in dance created by dance activists.
\end{abstract}

Keywords: Minangkabau dance, martial arts, movement identity

How to Cite: Asriati, A., Kosasih, A. \& Desfiarni. (2019). Silat as the Source and Identity of the Minangkabau Ethnic Dance. Harmonia: Journal of Arts Research And Education, 19(1), 71-83.

\section{INTRODUCTION}

Dance movement is an essential element in a dance, aside from other supporting elements such as dancers, clothing, music, property, and others.

Likewise in traditional Minangkabau dances, the movement showed in the dance is a very essential element. As an essential element, the movement may tell habitual activities pattern of the community. It also expresses the cultural values of its people (Asriati, 2005). Thus, the movement of Minangkabau traditional dance is a movement that tells the pattern of daily living activities of Minangkabau people in their respective district contexts and expresses their cultural values. For Minangkabau ethnic, their dance is tradition-based especially in a particular district and becomes a pride for the district and its penghulu (Asriati, 2005).

Therefore, penghulu, cendikiawan, ninik-mamak, cadiak-pandai and 'alim-'ulama have been evolving Minangkabau philosophies called "Religion-based Customs, Al-Quran-based Religion" (Adaik Basandi Syarak, Syarak Basandi Kitabullah/ABS$S B K)$ in various aspects of life. However, a question arises on its application towards Minangkabau traditional dance. How this philosophical value is considered in the movement of the dances also catches their attention.

It indicates that the movement elements in Minangkabau traditional dances

\footnotetext{
Corresponding author:

E-mail: afifahasriati@yahoo.com
} 
are not appropriate with the values contained in the philosophy. Erlinda (2012) sees that the influence of globalization and the capitalization of life have led to the development of Minangkabau dance towards the market demand. Their creativity adapts market demand and has even become a tool for industrial and commerce advertising today.

Indeed, cultural and religious values (the philosophy of ABS-SBK) are not obscured by new values, which are not in harmony with traditional and religious values. The existence of the hip shake movement in Minangkabau contemporary dance is one example of a movement that is not in harmony with the Minangkabau philosophy itself. The development of Minangkabau dance movements seems to be dominated by female dancers compared to male dancers. This matter makes Minangkabau dance can be uprooted from its cultural roots.

Historically, there was indeed a movement of Minangkabau dance that was not in line with religion (syarak), such as Lukah Gilo Dance (Desfiarni, 2004) which expresses and contains the value of shirk. Meanwhile, several movement prototypes are in line with the values of religion, such as the movement in Pasambahan dance, which has the value of glorifying guests with movement and clothing that reflects the value of religion (Asriati, 2012).

Based on the phenomenon described above, it is necessary to conduct an in-depth study that involves the concept of dance movement in general (dance elements) and the specific forms of Minangkabau dance movement. Especially in the framework of philosophical values embraced by Minangkabau people. Specifically, it can be formulated; what is the real basis concept of Minangkabau dance?

The purpose of this article is to find the Minangkabau dance movement concept in accordance with the philosophy of people. In other words, this article aims to prove either the traditional dance movements in Minangkabau are based on martial arts movements or other movements aside from martial arts movements. This finding is useful for choreographers as a guideline in creating typical Minangkabau dance movements in accordance with the Minangkabau people's identity.

\section{Dance and its relevance to the community}

Theoretically, this study is classified as a correlational study between dance as values of life and activities of its supporting communities because people's understanding of dance varies greatly. Zile (2014) explained that dance is the movement show from the translation of written notation while preparing a performance becomes the actual appearance or the show itself. In Pemalang, Wahyuni and Hartono (2014) found that the realization of the Slendang Pemalang Dance was in line with the elements of dance in the form of wiraga, wirama, and wirasa. The costumes are also in line with the characteristics possessed by the Pemalang community.

Kaeppler 1991 in Kwok (2014) argued that dances can be classified into three major groups; (1) kinesthetic, (2) ethnological approaches, and (3) dance scholars.

Kinesthetic is a dance that uniquely integrates deep personal experience with cultural structures. Thus, culture and individual experiences are inherent in the cultural values of a community.

While ethnological approaches are studies of dances that specifically use an ethnological approach. In the US, this study concerns five dimensions of Kaeppler; (1) dances as a performing art, (2) dances as a therapeutic method, (3) dances as culture, (4) dances as social, and (5) dances as history. First, as a performing art, a dance educates many strata and levels, especially at the level of philosophical and aesthetic values. Both of these values also integrate into one dance performance. Thus, the performance dance is a combination of substantive and technical values in a dance movement and form.

Second, dance as a therapeutic method can be meant as a combination of physical exercise and emotive processing which cannot be inseparable from the hu- 
man self. Dances integrate the physical and emotional parts of the self. This means that the human physical and emotions aspects are integrated activities.

Third, dance as a cultural phenomenon can be meant a symbol that symbolizes habits and non-verbal activities or means to communicate ideas, thoughts, and feelings. This point is very important for the development of human values. In addition, dance provides a code and communicates one's worldview through non-verbal motion or text. In short, dance is a cultural communication instrument that contains ideas, feelings, and thoughts symbolized in the form of motion and a series of meaningful human movements.

Fourth, dance as a social phenomenon provides a form of great strength from communal activities, unites and identifies social groups. It means we are able to know that the unity of society through the dance delivered by the community groups is an identity of the community.

Fifth, dance as a historical phenomenon can be meant as a statement or reflection of past cultural experiences that are explained, presented, and showed until now. It means that the dance that performs today is a record of the past cultural history experienced by a person or community of its supporters. Thus, it is pleased as a past state that is still remembered.

Kaeppler theory mentioned that traditional dances are actually a reflection of past traditions presented today that contain ideas, feelings and thoughts of a person or group of creators as a symbol of past conditions that unite physical and spiritual (emotional) movements, embraced by community supporters or social groups. They are either ideas or meanings of community activities (tradition) or philosophy and aesthetics, both textual and contextual values.

Therefore, Kaeppler theory can be used as a framework of thought or theoretical foundation for conducting a study on traditional dances in Minangkabau. Especially, in analyzing the contextual meaning of a dance or in the framework of giving the movement meaning of some traditional dances in some areas.

The third group approach is the dance scholar approach which emphasizes that the future dance study is focusing on cultural relevance of understanding history, social and ethnic diversity, and cultural understanding in our ever-volatile world.

In connection with the concept of dance and society above, Kiram (2000: 5) tries to express the concept and orientation of dance movement in general. He states that movements are a change in the place, position, and speed of the body or human body parts that occur in a dimension of space and time and can be observed objectively. The meaning of this movement is certainly not a movement in the meaning of physics but specifically for human movement. For example, changes in the place, position, and speed of the body or the human body part in walking, running, jumping and more.

Furthermore, changes in the place, position, and speed of the body or parts of the human body in dance according to Hutchinson (1974) in Labannotation or Kinetography Laban; the System of Analyzing and Recording Movement, and in the Knowledge of Dance Elements and Some Dance Problems by Sedyawati et al. (1986) can be left, right, forward, backward, upward, downward, to the left side, to the right side, and up to 27 types of movements that have been registered for the benefit of this notation. Laban made a map and a gesture of movement which he called Movement Family Tree (Hutchinson, 1974: 18), which until now is still used as a guide for researchers and practitioners of dance movements. Laban's concept and promises are still relevant for dance research and movement in particular, including for the grand theory of dance research (dance movements) of Minangkabau.

\section{Results of Research on Minangkabau Traditional Dance}

The dance movements in Minangkabau are traditionally based on traditional and religious values. It is generally ex- 
pressed by Naim (2004) that the value of $A B S-S B K$ as the philosophy of Minangkabau people is believed to be their identity. Naim sees that the problem is no longer at the level of theoretical concepts, but how their values are manifested in their social actions. According to Naim (2004: 50), these philosophical values are systemically and planned to be programmed into various aspects of life so that they become enlighteners and directors (suluah bendang) in Minangkabau people life in the future.

Moreover, four things can be understood from the opinion related to the elaboration of this philosophy in the future, such as (1) concrete steps must be conducted, (2) describing the value of this philosophy in government and social action, (3) doing well-programmed step, not incidental, and (4) do not let it run conventionally. This idea has been used as an official document in West Sumatra, that the ABS-SBK philosophy has become the philosophical foundation for religious life (Regional Regulation of West Sumatra No.9 of 2000 and No.27 of 2007).

In connection with the value of religion in dance movements, Gazalba (1977, p. 79) argues that Islamic ethics or morality determines whether an element of art (including movement in dance) is worth halal, makruh or haram. Then, Omar (1983: 57-58) argues that the laws of music art, sound arts, and dance art are legal (permissible), as long as other forbidden things do not follow them. When haram things follow it, then the law becomes haram too. On the contrary, when it is followed by things that Allah blesses, then the law becomes sunnah, such as celebrating a wedding party, circumcision, respecting guests, Eid Fitri, independence day, and others.

Besides, Omar said that the haram value of dance and movement in dance is not because of the substance itself. Next, Naim (2004) also mentioned that the real custom (Adat nan sabana adat) is absolute while supporting custom (adat istiadat and adat yang diadatkan) is a flourishing (ethics and aesthetics), which is elegantly used and adapted to the place and method of the Al Quran.

Then, dance movements are classified as an aesthetic classification (adat istiadat/yang diadatkan). At this aesthetic level, Naim (2004) argues that the philosophy of $A B S-S B K$ is the manifestation of Allah law (sunnatullah). Thus, customs that have been patterned in the culture must be free from the elements of shirk, khurafat and bid'ah because their main reference is religion and the reference of religion is Al Quran.

From all the explanations above, it can be understood that the movement in Minangkabau dance, in fact, must be in line, harmonious, in accordance with and based on the $A B S-S B K$ values which become the Minangkabau ethnic philosophy. It means that Islamic religious values must be shown in all expressions of Minangkabau dance movements. It does not express things that contrast with Islamic values. This philosophy is very useful for Indonesian choreographers to make the aesthetic value of Indonesian dance richness Hastuti and Supriyanti (2012). It can also be a differentiator with the aesthetic value of western dance patterns.

\section{METHOD}

This study used a qualitative approach that was used to collect appropriate Minangkabau dance movements data based on cultural values and $A B S-S B K$. The data collection techniques used were (1) FGD, (2) documentation, (3) observation, and (4) interview. The credible data obtained through triangulation, and they were analyzed by the model of Miles and Huberman (1992).

The flow chart of this research can be seen in Figure 1. In finding out the Minangkabau traditional dance movement concepts, one dance is set for one district in each representative district; (1) land area (darek) and (2) coastal area (pasisie). The land area (darek) is an area that belongs to the Luak area. Luak is a native area of Minangkabau culture. Whereas the coastal area (pasisie) is a seacoast area or an area that is influenced by the culture of the na- 
tive region of Minangkabau culture. The state of the coastal area (pasisie) has been influenced by many external cultures such as Malay, Portuguese and others.

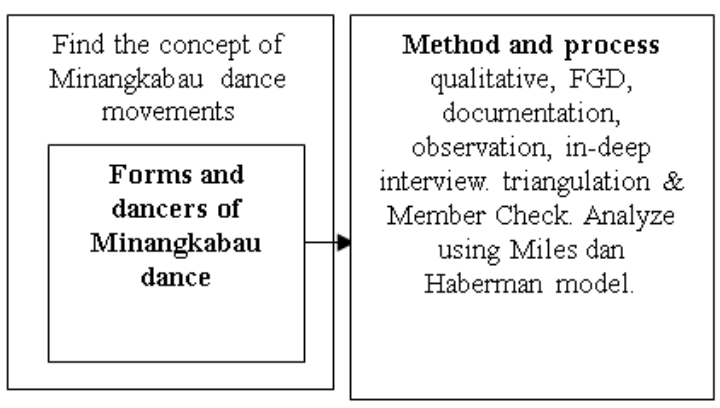

Figure 1. The conceptualization of Minangkabau dance movements

Furthermore, the land areas (darek) are represented by; (1) Mulo Pado dance from Padang Magek, representing the Tanah Datar district, (2) Piriang di Ateh Kaco dance from Bayue representing Agam district, and (3) Sarompak dance from Taeh Baruah representing Limo Puluh Kota district. Then, the coastal areas (pasisie) are represented by (1) Indang dance from III Koto Aur Malintang, Padang Pariaman district, (2) Pilin Salapan dance from Air Bangis West Pasaman district, and (3) Rantak Kudo dance from South Painan Pesisir Selatan district.

\section{RESULT AND DISCUSSION}

There were 6 dance samples taken into account in this study. These dances can be used as adequate data information in representing the basic concept of $\mathrm{Mi}$ nangkabau traditional dance movement.

\section{Mulo Pado Dance Movements Concept}

Mulo Pado dance is divided into the original and the contemporary dance. Mulo Pado dance movements were derived originally from silat. "Most of these dance movements are from silat" said the A.S. Dt Majo Dirajo (FGD, 2 June 2015). Meanwhile, other FGD participants stated that Mulo Pado dance movements performed by female dancers combined tradition and creation. It was revealed from the following FGD, " men don't want to dance anymore if this dance has mixed with the woman movements style. However, silat can only be done by men "(FGD, AS, Maji Dirajo, June 2, 2015). The point here was that Mulo Pado dance movement which showed during the FGD had combined the original and improved movement. Then, it was defined as women steps because the movements carried out were like people dancing and such movements were not suitable for men anymore. The movement was only suitable for women, while the suitable one for men was silat. The other FGD participants stated that the Mulo Pado dance had been modified. He said, "the opening of the dance was tradition, yet the show in a whole was a creation" (FGD, Syafwardi, 2 June 2015). It means that the opening stage can be categorized as the traditional movements, others were created.

In general, Mulo Pado dance movement danced by women was a contemporary dance. Syafwardi added that this dance movement was silat movement at first. Then, happy movements followed the rhythm showed that they were heartened after finding the Padang Magek area as a new settlement.

In addition, there were special rules for the movement of this dance, in which there must be Pasambahan movements at the beginning of the dance as a symbol of apology to God and humans, as revealed by the A.S. Dt Majo Dirajo (FGD, June 2, 2015). "The opening (the beginning of the movement) was the four steps movements begging an apology to earth and to heaven".

Therefore, the FGD above indicated that Mulo Pado dance movements had two versions that were the original and contemporary creation version. The original one was derived from martial arts movements such as attacking and parrying, while the creation version used silat movements in the opening only. Thus, the next movement was referred dancing. This dancing movement was only suitable for women, while the one that was suitable for 
men was silat movement.

Based on the data presented above, it was known that Mulo Pado dance was performed by 2 people. Initially, the male dancer did silat that was already mastered before they danced Mulo Pado (A.S. Dt. Majo Dirajo, FGD, 2 June 2015). This statement was justified also by other FGD participants.

At first, the movement in this dance was silat style since the skill of silat was only possessed by men who were warriors in silat. However, now it turned into another movement that was not silat. This new movement was only called dancing. Now, this dance is only danced by women in pairs (A.S. Dt. Majo Dirajo, FGD, 2 June 2015). The community accepted the gender movement change as it did not violate custom and $A B S-S B K$ philosophy (A.S. Dt Majo Dirajo, FGD, 2 June 20115). On the contrary, some ulama in Padang Magek were reluctant to accept this. He said that the religious did not allow it. However, for the sake of emancipation, it was finally not disputed. Thus, there were not even ulama who opposed it (Suhaili Anwar, Interview, 2 June 2015).

\section{Movements and Dancers Relation}

Furthermore, Suhaili Anwar (interview, 2 June 2015) stated that the combination of female and male dancers depended on the permissible movement, as long as it was not striking in terms of their movements. In contrast, Silat movements were taboo to be carried out by women in ancient time. Even, females were not allowed to go out of the house. It was not a big deal now due to the times and outside influences. Suhaili also mentioned that Mulo Pado dancers were male ideally. It was also noticed that in reality there were no more men who want to dance, and it was difficulty in getting it.

Based on the above expression, it can be understood that Mulo Pado dance in Padang Magek actually needed to be reorganized. Ideally, it should have been males as the original dancer who can dance this movement. In fact, because of emancipati- on, the change in dance needed to be monitored so that it has an inconspicuous movement in the meaning of Islam. It could be meant that women were tolerated to move dance as long as they were not against the criteria of Islam.

Whereas, this dance can also be performed by female and male dancers as well. They can be joined together as long as it was not opposed to the $A B S-S B K$ value said A.S. Dt Majo Dirajo (FGD, 2 June 20115). The female dancers did not show off their gestures and inappropriate dressing according to customary and religious standards.

From the data above, it can be found that the movement carried out by Mulo Pado dancers in Padang Magek was martial arts-based movement. Men danced this dance at first. However, due to the times, men were no longer willing to dance, so women took over this dance by changing their movements according to appropriate steps and movements for women. It no longer used the martial arts movements performed by male dancers before. Because, it is only in the initial movement greeting God, nature, and the audience. This change was tolerated by the community, both by traditional stakeholders, traditional dance activists, and district ulemas.

\section{Piriang di Ateh Kaco Dance Movements Concept}

Piriang di Ateh Kaco dance in Bayue reflected community farming activities. The farming movement was the dominant motive for this dance with attractive jumping and rolling on broken glass. This type of dance was a tradition and some were already improved as well.

Piriang di Ateh Kaco dance movements illustrated the daily activities of Bayue community. This dance told the story of farming activities in the rice fields, from hoeing to harvesting and bringing rice home (Dj. B. Dt Pamuncak, 31 May 2015).

It can be seen from its traditional movement originated from silat while women performed the contemporary one. Dj. B. Dt 
Pamuncak (FGD, May 31, 2015) stated that this dance should be sent back to the original culture that did not show rocking hip. This dance should not be vulgar. Thus, according to them, Minangkabau dance should be replaced to its original culture in which no movement rocked the hips, no one swayed in the swing.

Additionally, Piriang di Ateh Kaco dance also showed the movement of stepping on glass, rolling on glass and other attractions. Regarding this matter, the FGD participants included Y.E. Imam Panjang (FGD, 31 May 2015) stated that it was not allowed to use real magic. It was allowed only to use ma'rifat power with prayer. Then, both can be applied. In the past, there was a debus man dance that was similar to this dance. Later, the music was the original music. Some people can do it if there was a handler. There were two kinds of handlers called the sihir kulipah that asked for hak besi katapuang besi and tarekat expert that used the ma'rifat power goes to Allah. Finally, these men were not eaten iron. As a result, there were two classifications of this dance; sihir and dzikir.

There were some impossible movements for normal people in this dance. According to them, it was due to the influence of magic and zikr. Ulama in Bayue did not accept the influence of magic. While the two basic types of movements (magic and zikr) were in this district. In summary, the Piriang di Ateh Kaco dance depended on its commander (the handler). Whether the handler was from surau or lapau. If the handler was a person from surau, then it used dzikir. On the contrast, if the person was from lapau, then it was performed through magic. These approaches were the same concept and purpose that was to provide entertainment to the public in the crowd and showed up the talent.

The results of the FGD indicated that Piriang di Ateh Kaco dance movements were carried out to illustrate farming activities in the fields started from hoeing, harvesting and bringing rice home. The style of movement was silat. When the dance performed by women, the rocking movement of the hips and pitch the swing should be avoided. In addition, to farming activities, rolling and stepping on the glass movements, which can be done through dzikir or magic. Magic doing was not in line with Islamic value, yet zikr was impossible because nowadays there was no one praised God. Therefore, the movement through magic was not in line with the Minangkabau philosophy.

\section{Movement and Dancers Relation}

Piring di Ateh Kaco dance movements were originally carried out with a pattern of martial arts by men only. However, in its development, their movements adapted to the proper movements for female dancers. With the presence of women dancers, the custom and religion gave limits to movements that do not provoke lust or erotic. As Dj. B. Dt Pamuncak stated in (FGD, 31 May 2015) that the movement of women in public must maintain the honor of being in proper movements and close their genitals.

Whereas, there were no movements that made women and men in contact. It would be a problem if this happened because the community could not accept it. Dj. B. Dt Pamuncak (FGD, 31 May 2015) said that this is a new problem that should be resolved. Ideally, Minangkabau female should be replaced as it was before (Dj. B. Dt Pamuncak, FGD, 31 May 2015).

The FGD above explained that male dancers performed the original pattern of movements in Piriang di Ateh Kaco dance as it was mentioned by adat and ulama in Bayue. They argued that this dance prioritized male dancers, yet in its development, it has now been danced also with the proper movements carried out by women. Finally, the FGD participants gave the criterion if women want to be in charge of this dance. This case was also permissible under conditions that the movement must be appropriate traditionally and religiously. Ideally, according to them, Minangkabau women must be replaced to their nature as Minangkabau women. When they move or dance, their movements were deemed ap- 
propriate and according to Islamic values.

\section{Pilin Salapan Dance Movements Concept}

Pilin Salapan dance in Air Bangis illustrated the hard spirit of struggle toward invaders. The most dominant movement used in this dance was the wooden hitting and jerking movements, while the steps were called the Malay style moves (Maiwalis, Interview, June 1, 2015).

It turned out that in its development now, this dance was also danced by an adult female. In fact, it was not allowed by ulama, as revealed by an ulama said, "the movement was fast" (Idmansyah, FGD, 1 June 2015). Unlike Idhamsyah's opinion, a Bundo Kanduang, who is called "Puti", stated that this dance was in line with $A B S$ $S B K$. It had standing up movement only, so it was fine (Rosna, Interview June 1, 2015).

Finally, the FGD and interview above showed that the adult female movement criteria based on $A B S-S B K$ should not be vulgar. It was fine to be performed by a male dancer because the movement was standing and a step only.

\section{Movement and Dancers Relation}

Men danced pilin Salapan Dance in Air Bangis Pasaman Barat at first. As revealed by Maiwalis (Interview, June $1,2015)$ that all dancers were male who struggled against the invaders. The same thing was expressed by Asrial (FGD, June 1, 2015) Pilin Salapan dance was only for men. However, women danced it now. Then, female and male dancers were in contact. In fact, they were not muhrim and this matter was actually violated. Sometimes there is contact and collision because the movements were getting closer.

The data and information above showed that Pilin Salapan dance movements also changed as Mulo Pado dance in Padang Magek. The process of change was also similar. The movements were originally carried out by men. Next, it could be performed by women with appropriate movements for women. Then, a duet between men and women movements. This duet was generally not permissible according to ulama in Air Bangis. Ideally, as Asrial, S.Ag. suggested (FGD, June 1, 2015) "Pilin Salapan dance is ideally danced by men only". Then Asrial asserted that "I think this dance should be replaced as it was to the initial form, the dancers were all men". This statement was supported by Aidil Haqhi (FGD, June 1, 2015) "In my opinion, this dance should be replaced to the initial form, all-male dancers". The fact, it was rare for men who wanted to dance.

In short, Pilin Salapan dance was essentially carried out by men because of its dynamic movements. Then, it was later danced by women and women-men duet. Cerdik pandai, penghulu and alim-ulama who participated in the FGD and interview stated that this dance needed to be replaced to its original value. Women who have not yet been mature was one solution.

\section{Indang Dance Movements Concept}

Indang dance in III Koto Aur Malintang Padang Pariaman was a popular dance, known by almost all regions in West Sumatra and even outside West Sumatra. Most people knew this dance. Indang Dance was used to spread Islam in the Minangkabau. Now, it was also used as entertainment. The very famous creation of Indang dance was Dindin-Badindin.

Indang dance was danced by sitting cross-legged. Dancers' hands and bodies were centered of the movements and it was carried out with martial arts. The movements of men and women were the same in Indang dance. It was not a big deal for them as revealed by Rajo Rangkayo Sardewo (FGD, June 16, 2015). He said that the movement of men was as same as the movement of women, then it was no problem for society. It could be meant that the movement in this dance was not disputed both for male and female. There was nothing against traditional and Islamic religious values.

Previously, Indang dance was dominated by men, said Rajo Rangkayo Sardewo (FGD, June 16, 2015). This statement was supported by other FGD participants 
(FGD observations, June 16, 2015) that mention "The dominant here could be meant as men dance more often than women ...". While the combination of men and women dancers, most recently, had been publicly shown up.

\section{Sirompak Dance Movements Con- cept}

Sirompak dance movement in Taeh Baruah was rooted in martial arts movements and performed by one dancer. This dance was performed using music originating from the sound of saluang Sirompak. Saluang and dance movements were merged with each other and inseparable. Formerly, the movement of Sirompak Dance was full of magic values and done secretly. Today, this dance was showed in public because there was no magic anymore. The movement of Sirompak dance could be seen in Figure 2.

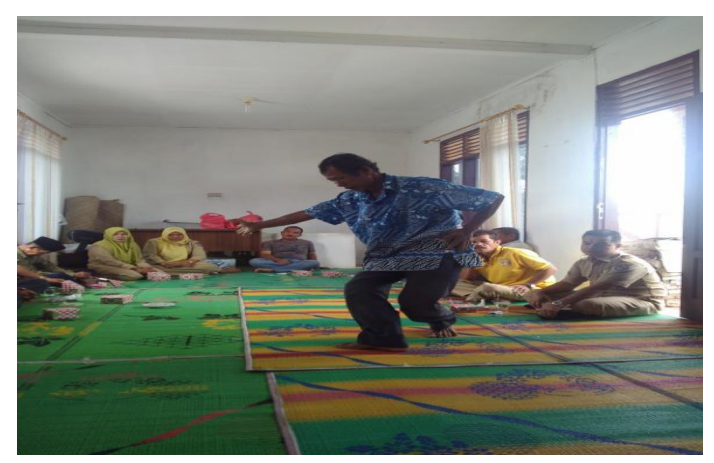

Figure 2. Sirompak dance movement in

Taeh Baruah performed by Ute

(Documentation: Afifah Asriati, $25^{\text {th }}$ November 2015)

The movement was in balance with the accompaniment of the music, "if there is no music, how can I dance? Ute said “(FGD, 25 November 2015). Ute added that after the music and the saluang were played, he felt as if someone was calling and his hands would move on their own. When the music rises then the movement rises, on the other hand when the music goes down then the motion goes down. The other dance had a title. This dance hangs from the low and high pitch of the chime. If the height of the voice me- ant high, so did the dance (Ute, FGD, 25 October 2015). It was interpreted that the movement was very dependent on music, added to the height of the musical tone and also the level of dance movements and vice versa. The movements were influenced by musical magic instruments, which according to them the poems sung by the accompaniment of Sirompak have a distinctive tone that can appeal to those who listen to them. The dancers did not fully realize that they did the movements. The movement and music were supported with silat clothing, namely black clothes, galembong pants and destar.

When it was related to custom and religious values, the results of the FGD stated that the dancers knew that this dance was in contrast to adat and religion. However, all elements of dance were not related to women during the performance. Then, this matter did not raise a problem in adat and Islamic view. Moreover, the dancers were really fighter in general (Ute, FGD, 25 November 2015).

\section{Sirompak Dance Movements Concept}

Rantak Kudo dance was taken from the name of Benten's wife, Rantak Kudo, who described to train her child walking. Kudo's face as a mother guides his child's hand so that he can walk well and quickly. This dance was well-known in the South Painan (Arita, FGD, 26 November 2015).

Rantak Kudo dance movements were played based on the silat movement. "This dance was indeed the movements of silat, it guided children to walk, practice walking (Arita, FGD, 26 November 2015). There was no graceful movement as the researcher showed during this FGD. "There were 4 main movements such as eye movements, head, and incisive steps like in martial arts movements" (Rini Delvita, FGD, 26 October 2015). Thus, this dance had strong power and its motion style based on the silat style. The four basic movements were taken from Benten's activities as father and Rantak Kudo as a mother who taught their child to walk. The names of the movements were Jinjiang Bantai, Titi 
Batang, Rantak and Lenggang Karaia.

The four movements had their own meaning. Literally, Jinjiang Bantai interpreted as a father, namely Benten had responsibility for his family. There was Thursday market in Painan where Benten went to the market and returned carrying groceries by carrying it. Lengang Karaia could be described as walking upstream (Arita, FGD, 26 October 2015). It was in accordance with Minangkabau people's philosophy "Alam Takambang jadi Guru" (Nature is a teacher). The movement in this dance was a daily activity of a new family that has just had children. The movement of this dance was not becoming a big problem according to traditional leaders, yet there was a limitation in the way of shaking and rocking (Asril, FGD, October 26, 2015).

Therefore, it would be discordant if rocking was included in this dance since it was not in line with Minangkabau customs. This opinion was strengthened by Arita (FGD, November 26, 2015) "There was no hip shaking in Rantak Kudo dance since shaking hip was forbidden in Islam".

The FGD concluded that the basic movement of Rantak Kudo dance was silat and there was no hip shaking movement because it was contradicted with adat and religion.

In ancient times, Rantak Kudo dancers were male only. "At first, this dance was danced by men only. Women should not take part in art because it was taboos for Minangkabau people. (Arita FGD, 26 November 2015). However, this dance was performed by men and women in its development. "In my opinion, since the beginning of my elementary school, Rantak Kudo dance was performed by female and male, not male only" (Asril, FGD, October 26, 2015). Today, Rantak Kudo dance was performed with the combination of men and women dancers. "It seemed that the traditional leaders did not have a problem, Asril (FGD, October 26, 2015) everything was in line with adat and religion ".

That was to say, there was no discrepancy in Rantak Kudo dance based on the view of adat. In fact, this was an asset for the Pesisir Selatan. This statement was in line with the figure of Bundo Kanduang Hasnidar (FGD, 26 November 2015) who stated that "Rantak Kudo Dance was a good dance without something negative". This was the same as the traditional figure above, who said that there was nothing contradictory of Rantak Kudo dance seen from the aspect of adat and religion.

On the other side, Rantak Kudo dance was also danced in pairs. This dance was an even-numbered dance. "There was the only group in pairs for this dance in East Painan"(Arita, FGD, 26 November 2015). The dancers could be both man and women and they did the movement in the same way. "This dance was a duet dance since there were simultaneous and opposites fend off "(Rini Delvita, FGD, Nov. 26, 2015).

Conceptualization and Discussion Means

Based on the results of the research described above, it was found that the movements of Minangkabau dance were in line with the context of adat and religious values. These movements were derived from martial arts or silat which became the typical style of Minangkabau dance. There were some dances as evidence for this fact such as (1) Mulo Pado Dance (2) Piriang Diateh Kaco Dance, (3) Indang Dance, (4) Sirompak Dance, and (5) Kudo Rantak Dance. On the other hand, Pilin Salapan Dance adapted from Malay culture had influenced the Minangkabau dance. Thus, Pilin Salapan dance was not included in the stage of analyzing the conceptualization of Minangkabau dance. These findings could be mapped in the following schematic description (Figure 3).

It can be seen from the schemata above that the basic motions of Minangkabau dance movements were dominated by silat. Then, it could be stated that without silat movement, Minangkabau dance would lose its identity. As Sedyawati (1986: 64) argued that nature as a world and human as culture unconsciously formed the character motions in dance. These two fundamental settings had a significant effect on 
the formation of motions in dance and it turned out to be the identity of the community. This conclusion was in line with Asriati's (2005) findings that the Piriang Sulueh dance in Pariangan also reflected the daily activities of the community and its movements were silat-based movement.

1. Mulo Pado; At first, it was performed by men only with silat movement by attacking and blocking. Today, these silat movements were showed only at the beginuing of the performance. The rest movements were adjusted to women appropriateness in dancing.

2. Pitiang Diateh $\mathrm{Kaco}$; At first, it was only stancing and rolling done by men only using magic and dzikir. Today, women were allowed to dance under term and condition using appropoate silat motions dominated by hands movement and no rocking hips.

3. Indang; It was focusing on hands and body movements using silat motion that can be danced by mer, women, or both in combination.

4. Sitompak; It used silat motions perfomed by fighters and no more magic in music.

5. Rantak Kudo; It was dance in silat motions by both men and women without rocking the hips.

The Uniqueness of Minangkabau dance Movements The dances perfonmed using silat motions such as attacking, blocking, parrying, rolling, pritunggre, hands and

legs movements. It was not allowed for women to rock the $\underbrace{}_{\text {hips }}$

Figure 3. Scematic description of the dances

Then, the motions drew in Figure 3 were also in line with Hadi (2006) who noted that the movement of Minang dance was derived from silat resulting into various forms of dance, including Galombang movement in Randai (Rustianti et al., 2013). Based on adat point of view, silat could only be done by men. Hadi's opini- on was in line with the alim ulama and adat figures of Padang Magek district who stated that the movement of male dance was originated from silat (Asriati, 2015). Huri Adam's movement for women, for instance, was not erotic and sensual, these movements were not carried out beyond the ethical and aesthetic limits of Minangkabau culture which were based on religious and adat values (Utama, 2009).

Based on the data and explanations above, Minangkabau dance had an identity of silat in terms of its motions. This silat motion maintained Minangkabau dance identity in which without silat it was not the actual Minangkabau dance. Although there was a change in the life of the Minangkabau people to be more modern direction, it did not necessarily change local values. The local values were still retained in the dance. This finding was supported by the Indrayuda (2016) study which concluded concluding:

"As a result, the change found in Minangkabau dance creation is limited only to the visual or formation, but content still reflects and illustrates the cultural identity of Minangkabau society through the local wisdom value".

Furthermore, local wisdom value for the Minangkabau culture was silat that fundamentally based on Adat basandi Syarah, Syarak Basandi Kitabullah (ABS-SBK) that custom was based on religion, and religion was based on Al Quran.

Then, Yunus (2013) stated that Minangkabau customs had four Islamic values: polite, kind-hearted, good manner, and elegant. These four values controlled creativity and art performances. This statement was also in line with Hadi's view who said that there were things for women in adat called "discordant" (inept), such as sumbang duduak, sumbang tagak. This could be meant that women had to avoid rocking hips.

Kadir's research (in Soedarsono (2002, p. 39-43) found that the Piriang di Ateh Kaco dance performance was always led by a person called Kulipah who 
was responsible for the performance of the show. It was the same as the researchers found in Piriang di Ateh Kaco dance from Bayue district. Kadir revealed that the magic spell Kulipah during the performance was animism and it resulted in some attractive forms of irrational and mystical. Hadi (2006) argued that dances that were used spells can damage the aqeedah and they must be avoided and eliminated ".

Naim (2004) stated that the philosophical concept of ABS-SBK was actually the manifestation of natural law in the form of sunnatullah that contacted with Islam. Adat was patterned and cultured habit, inevitably had to be free from the elements of shirk, khurafat and bid'ah since they were contrary to Islamic values.

\section{CONCLUSION}

Based on the traditional dance samples examined in this research-based conceptualization means, it is found that silat movements that generally and fundamentally found in each observed dance were in line with Minangkabau philosophical values. They are stylized in an aesthetic form. Finally, all the movements observed in the motion of the Minangkabau dance are revealed to be concrete and consistent. The value of the $A B S-S B K$ philosophy is a substance value (essential) contained in Minangkabau customs.

The next conclusion is silat as the basic motion of Minangkabau dance movements is in line with adat and Islamic values. The uniquenesses of silat motion in Minangkabau dance movement are attacking, blocking, parrying, rolling, pitunggue, legs and hands movements. These movements are the original basic concept of the cultural movements of a person who performs silat. This fact makes Minangkabau dances are performed by men. On the other side, women were initially barred from dancing because their movements were inappropriate for Minangkabau women. The appropriate movements for women dancers emerged when they begin to be involved in the dances.
In addition, the dance movement concept that is appropriate for women based on adat and religion; it is not rocking hip and erotic in legs, body, hands, head and other movements, such as rolling, attacking and parrying. It is also forbidden to be in contact with men if the dance is performed in combination or duet. (Journal \& 1985, n.d.)

\section{ACKNOWLEDGMENT}

Thank you to the Ministry of Research, Technology and Higher Education (DRPM) for funding this research in the Fundamental research scheme.

\section{REFERENCES}

Asriati, A. (2005) Gaya Tari dalam Perspektif Kontekstual (Kajian terhadap Tari Piriang Suluah). Jurnal Ilmiah Pendidikan dan Kebudayaan, 11(2), 126-143.

Asriati. (2015) Konseptualisasi Bentuk Tari Minangkabau dalam Konteks Nilai $A B S-S B K$. Research Report of Universitas Negeri Padang.

Erlinda. (2012) Diskursus Tari Minangkabau di Kota Padang, Estetika, Ideologi, dan Komunikasi. Padangpanjang: Institut Seni Indonesia (ISI) Padangpanjang.

Gazalba, S. (1977). Pandangan Islam Tentang Kesenian. Kuala Lumpur: Pustaka Antara

Hadi, W. (2006) 'Dunia Hiburan Tanpa Perempuan: Kekuatan dan Ciri Utama Tari Minang'. Paper presented on Contemporary Dance Festival (MCDF). 12 December 2006 at STSI Padang Panjang.

Hastuti, B, B. dan Supriyanti. (2015) Metode Transformasi Kaidah Estetis Tari Tradisi Gaya Surakarta. Panggung, 25(4), Retrieved from https:// jurnal.isbi.ac.id/index.php/panggung/article/view/43/0.

Hutchinson, A. (1974) Labanotation or Kinetografphy Laban (Second Edition), London, Oxford University Press.

Indrayuda. (2016) The Existence of Local 
Afifah Asriati, Ahmad Kosasih, Desfiarni, Silat as the Source and Identity of the Minangka- 83

Wisdom Value Through Minangkabau Dance Creation Representation in Present Time'. (Online), 6(2). Retrieved from https://journal.unnes. ac.id/nju/index.php/harmonia/ article/view/6146/5701. November 2017.

Kiram, Y. (2000). Belajar Motorik. Jakarta, Proyek Pembinaan Tenaga Kependidikan Dikti.

Kwok, M. (2014). Dance and Cultural Identity among the Paiwan Tribe of Pingtung County, Taiwan, Dance Research Journal, 11(1) 3540. Retrived from https://doi. org/10.2307/1477845 Published

Miles, M, B., dan Huberman, A. M. Analisis Data Kualitatif. Translated by Tjetjep Rohendi Rohidi. Jakarta: Universitas Indonesia Press.

Na'im, M. (2004). Dengan ABS-SBK (Adaik Basandi Syara', Syara' Basandi Kitabullah) Kembali ke Jati Diri, dalam buku Minangkabau yang Resah (ed., Latief, et al.,) Bandung: Lubuk Agung.

Omar, T. H., (1983) Hukum Seni Musik, Seni Suara, dan Seni Tari dalam Islam. Jakarta: Penerbit Widjaya.

Rustianti, S., Djajasudarma, F., Caturwati, E., Meilinawati, L. (2013). 'Estetika Tari Minangkabau dalam Kesenian Randai: Analisis Tekstual dan Kontekstual'. Panggung, 23(1). Retrieved from https://jurnal.isbi.ac.id/index. php/panggung/article/view/86/ manual/PanduanOJS.pdf

Sedyawati, E., Parani, Y., Mugianto, S., Soedarsono., Rokhyatmo, A., Suharto, B., dan Sukidjo. et al. (1986) Pengetahuan Elemen Tari dan Beberapa Masalah Tari. Jakarta: Direktorat Kesenian, Departemen P dan K.

Soedarsono. (2002). Seni Pertunjukan Indonesia: Di Era Globalisasi. The Third Edision. Yogyakarta: Gadjah Mada University Press.

Utama, I. (2007) “Kesenian Minangkabau Masa Kini: Antara Tradisional dan Gagasan Modern." Paper presented on 2nd International Conference on Southeast Asia Department of Southeast Asian Studies, Faculty of Art and Social Sciences. Universiti Malaya, Kuala Lumpur, Malaysia 3-4 December.

Wahyuni, E dan Hartono (2014). The Role of Kaloka Art Studio in Traditioning Slendang Pemalang Dance as The Region Identity in Pemalang, Catharsis, Retrieved from https://journal. unnes.ac.id/sju/index.php/catharsis/article/view/23078

Zile, J.V. (2014). What is the Dance? Implications for Dance Notation. Dance Research Journal. https://doi. org/10.2307/1478079, Published online: 01 July 2014. 